\title{
Multidisciplinary Cancer Conference: Preliminary Experience in Cranio-Maxiollofacial Surgery
}

\author{
Julia M Priller ${ }^{1 *}$, Monika Schanbacher ${ }^{1}$, Gerald Sendlhofer $^{2,3}$, Christian Hörath ${ }^{1}$, Katja Schwenzer-Zimmerer ${ }^{1}$ \\ From Safety in hospitals: from strategy to implementation Annual Scientific Meeting 2015 \\ Graz, Austria. 29-30 September 2015
}

\section{Background}

Multidisciplinary Cancer Conferences are established in several medical fields since decades [1] and the number of itself and discussed cases rises [2]. In Cranio-Maxillofacial Surgery the diagnosis and treatment of cancer is one main focus. All over the world there is an increase of the incidence rate of oral cancer registered [3]. Furthermore tumours of different entities of the head and face are treated in this specialist medical area. Therefore it is necessary to focus on a frictionless treatment without time loss by involving various medical specialists. Any communication in Multidisciplinary Cancer Conferences is the first step toward a successful therapy.

\section{Materials and methods}

The Cranio-Maxillofacial Surgery Multidisciplinary Cancer Conference takes places in a 14-day interval. The number of discussed cases and the participation of the multidisciplinary team was evaluated from 2012 till 2014.

\section{Results}

Discussed cancer cases continuously increased over time. In 2014 when compared to 2013 an increase of 88 percent was apparent.

The attendance of required disciplines was only documented in 50 percent of cases.

The departments of Oncology, Radiotherapy and CranioMaxillofacial Surgery participated in 100 percent in the documented Cancer Conferences.

\section{Conclusion}

Because of increasing cancer cases it is important to have a Multidisciplinary Cancer Conference. The evaluation

\footnotetext{
* Correspondence: julia.priller@medunigraz.at

'Division of Oral and Cranio-Maxillofacial Surgery, Department of Dentistry and Maxillofacial Surgery, Medical University of Graz, Graz, Austria Full list of author information is available at the end of the article
}

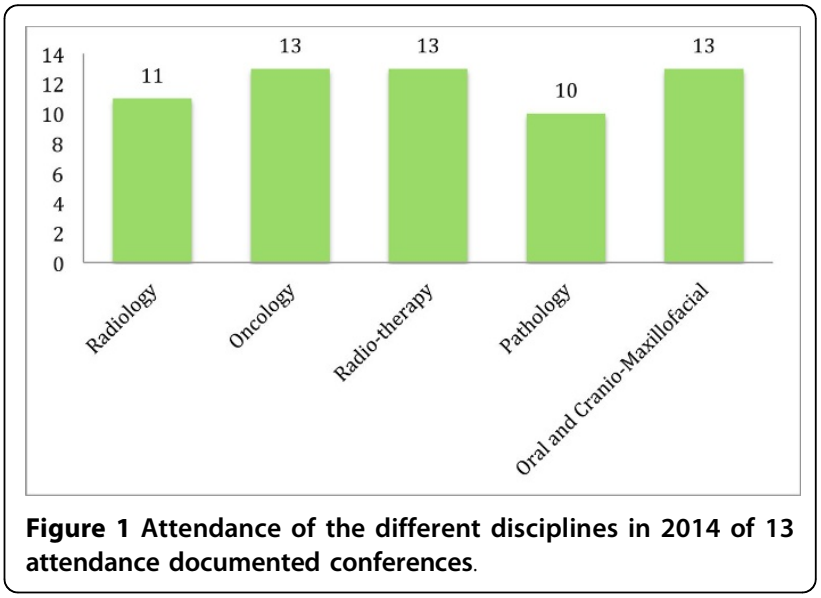

show that only a continuously and well documented Conference is the only option to treat patients interdisciplinary. Valuable time in cancer therapy must not be delayed. As a result of the fusion with the ENT Cancer Conference the new Multidisciplinary Cancer Conferences can take place weekly since June 2015. A standardised discussion seems to be the most important factor to secure the quality level.

\section{Competing interests \\ There are no competing interests.}

\section{Authors' details}

${ }^{1}$ Division of Oral and Cranio-Maxillofacial Surgery, Department of Dentistry and Maxillofacial Surgery, Medical University of Graz, Graz, Austria. ${ }^{2}$ Division of Plastic, Aesthetic and Reconstructive Surgery, Department of Surgery, Medical University of Graz, Graz, Austria. ${ }^{3}$ Executive Department for Quality and Risk Management, University Hospital Graz, Graz, Austria.

\section{Published: 30 October 2015}

\section{References}

1. Gross GE: The role of the tumor board in a community hospital. CA Cancer J Clin 1987, 37(2):88-92. 
2. Brar SS, Provvidenza C, Hunter A, Victor JC, Irish JC, McLeod RS, et al: Improving multidisciplinary cancer conferences: a population-based intervention. Ann Surg Oncol 2014, 21(1):16-21.

3. La Veccia C, Tavani A, Franceschi S, Levi F, Corrao G, Negri E: Epidemiology and prevention of oral cancer. Oral Oncol 1997, 33(5):302-312.

doi:10.1186/2056-5917-1-S1-A23

Cite this article as: Priller et al:: Multidisciplinary Cancer Conference:

Preliminary Experience in Cranio-Maxiollofacial Surgery. Safety in Health 2015 1(Suppl 1):A23.

Submit your next manuscript to BioMed Central and take full advantage of:

- Convenient online submission

- Thorough peer review

- No space constraints or color figure charges

- Immediate publication on acceptance

- Inclusion in PubMed, CAS, Scopus and Google Scholar

- Research which is freely available for redistribution 